\title{
NUTRITION IN THE PRODUCTION AND QUALITY OF SEEDLINGS OF THE BRAZIL NUT (Bertholletia excelsa H.B.K.) IN NORTHERN BRAZIL
}

\author{
Aline das Graças Souza ${ }^{1 *}$, Oscar Jose Smiderle², Renata D. Menegatti ${ }^{3}$
}

\begin{abstract}
The Brazil nut (Bertholletia excelsa H.B.K.) is fast-growing, and can be used in reforestation. However, the use of the species in reforestation is still uncommon, mainly due to production costs, with substrate and fertiliser being the most-costly components. Based on the above, the aim of this study was to evaluate growth and quality in seedlings of the Brazil nut both with and without nutrient solution. The experimental design was completely randomised in a 2 x 10 factorial scheme: treatments with and without the addition of nutrient solution and 10 evaluations at intervals of 45 days. The variables to be analysed were height, stem diameter, dry shoot weight, root dry weight, total dry weight and the Dickson quality index. When analysing shoot dry weight (SDW), a gain of $85 \%$ was found from adding the nutrient solution, compared to the absence of nutrient solution, whereas for the variable root-system dry weight (RDW), the gain was $43 \%$. The addition of nutrient solution is suggested for accelerating the growth and development of high-quality seedlings of Bertholletia excelsa for commercial use.
\end{abstract}

Keywords: Amazon, Dickson quality index, forest product, Roraima.

\section{NUTRIÇÃO MINERAL NA PRODUÇÃO E QUALIDADE DE MUDAS DE CASTANHA- DO-BRASIL (Bertholletia excelsa H.B.K.) NO NORTE DO BRASIL}

\begin{abstract}
RESUMO - A castanheira-do-Brasil (Bertholletia excelsa H.B.K.) apresenta rápido crescimento e pode também ser utilizada em reflorestamento. No entanto, o reflorestamento com a espécie é ainda reduzido, devido principalmente aos custos de produção, sendo o substrato e adubação os principais componentes deste custo. Com base neste contexto, objetivou-se avaliar o crescimento e a qualidade de mudas da castanhado-brasil por meio da ausência e presença de solução nutritiva. O delineamento experimental utilizado foi o inteiramente casualizado em esquema fatorial 2 x 10, tratamentos com e sem adição de solução nutritiva e 10 avaliações a intervalos de 45 dias. As variáveis analisadas foram: a altura, o diâmetro do caule, massa seca da parte aérea, raízes, massa seca total e índice de qualidade de Dickson. Ao se analisar a massa seca da parte aérea (MSPA), verificou-se ganho de $85 \%$ por meio da adição de solução nutritiva quando comparado com a ausência de solução nutritiva, enquanto para a variável massa seca do sistema radicular (MSSR) o ganho foi de 43\%. A adição de solução nutritiva é indicada para acelerar o crescimento e desenvolvimento de mudas de Bertholletia excelsa com alta qualidade para uso comercial.
\end{abstract}

Palavras chave: Amazônia, indice de qualidade de Dickson, produto florestal, Roraima.

\footnotetext{
${ }^{1}$ Bióloga, Dra., Professora, Institute Federal of Roraima, Amajari-RR, 69.303-340, Brazil. *Corresponding author. Tel. 95 999046104. E-mail address: aline.souza@ifrr.edu.br.

${ }^{2}$ Eng.-Agro, Dr., Pesquisador, Brazilian Agricultural Research Corporation - Embrapa Roraima, Boa Vista-RR, 69301-970, Brazil.

${ }^{3}$ Eng. Florestal, Doctoral Student in Plant Physiology, Federal University of Pelotas, Capão do Leão-RS, 96010-900, Brazil.
} 


\section{INTRODUCTION}

Forests that include the Brazil nut (Bertholletia excelsa) cover an area of approximately 325 million hectares in the Amazon and extend to Venezuela, Colombia, Peru, Bolivia and Guyana (Lorenzi, 2008). The densest forest formations which include the species occur in Brazil.

The Brazil nut can be considered a key species for combining conservation with development, as it is abundant in the Amazon region (Tonini, 2011), harvested almost exclusively in natural forests, and due to the robust market demand, exploited by various communities in the short term and at low cost, in addition to the low environmental impact of the harvest.

One of the great challenges of extracting the Brazil nut is to increase fruit production without compromising sustainability. Native trees begin production at eight years of age and reach maximum production at twelve. In grafted trees (buds), production starts at 3.5 years, and harvesting takes place from January to February and from April to May (Maués et al., 2015).

A lack of expertise in the techniques for producing seedlings of the Brazil nut is one of the main limitations encountered by nurserymen and producers; this highlights the need for studies that seek to improve production methods for the species, in order to obtain quality seedlings of commercial standard, genetic identity and good initial performance in the field (Borges et al., 2011).

Growth analysis is a very important method of evaluating the different responses of plants that are influenced by certain agronomic practices (Gonçalves et al., 2012; Corcioli et al., 2014; Pias et al., 2015; Moura et al., 2015). In this respect, the use of nutrient solution has proved to be a viable alternative, and has been applied to the production of seedlings of various crops (Oliveira et al., 2017).

Species cultivated with nutrient solution include vegetables, medicinal plants, ornamental plants and, more recently, fruit and forest species (Furlani, 1999; Rozane et al., 2011; Freitas et al., 2011; Souza et al., 2011a; Souza et al., 2011b; Souza et al., 2013; Souza et al., 2015; Smiderle
\& Souza 2016; Smiderle et al., 2016; Smiderle et al., 2017a, Souza et al., 2019).

There has been little study of the techniques of seedling production, including the growth and development cycle of the Brazil nut with the addition of nutrient solution under nursery conditions. For this reason, research should be carried out to find the ideal fertiliser for the species, and thereby ensure gains in Brazil-nut production.

Based on the above, the aim of this study was to evaluate growth and quality in the Brazil nut (Bertholletia excelsa) with and without nutrient solution.

\section{MATERIAL AND METHODS}

The research was carried out at the Seed Analysis Laboratory and seedling nursery of the fruit-farming sector of Embrapa Roraima, located in the Industrial District at Km 8 of the BR 174 highway, 02 ${ }^{\circ}$ '28' $\mathrm{N}$ and $60^{\circ} 43^{\prime} 54^{\prime \prime}$ $\mathrm{W}$, at an altitude of $90 \mathrm{~m}$. The city of Boa Vista is located in the Tropical Climate Zone, and has no extremely dry season or average monthly temperature below $18^{\circ} \mathrm{C}$. According to Köppen, the climate is tropical humid, type Aw: a rainy tropical climate, warm and humid, with a rainy season in the summer; the driest month has a rainfall of less than 60 $\mathrm{mm}$. Average annual rainfall is $1,750 \mathrm{~mm}$, air temperature is $26.7^{\circ} \mathrm{C}$ and relative humidity is $79 \%$ (Araújo, 2001).

The species used was the Brazil nut (Bertholletia excelsa); the seeds for producing the seedlings came from an area of Bertholletia excelsa set up in September 2006 in the Serra da Prata Experimental Area of Embrapa Roraima, located in the district of Mucajaí, in the State of Roraima.

After germination, the seedlings were grown in beds containing washed medium sand. Once they had a reached a height of five centimetres or displayed two pairs of true leaves, they were transplanted into plastic bags containing 2 litres of sand + soil substrate $(3: 1 \mathrm{v} / \mathrm{v})$. A chemical analysis of the substrate (Table 1 ) was carried out by the Plant Substrate Analysis Laboratory (LASPP), of the Federal University of Lavras.

Table 1 - Chemical characterisation of the substrate used for the production of seedlings of the Brazil nut (Bertholletia excelsa)

\begin{tabular}{|c|c|c|c|c|c|c|c|c|c|c|c|c|c|c|c|}
\hline Substrate & $\mathrm{pH}$ & $\begin{array}{c}\mathrm{P} \\
\mathrm{modm^{-3 }}\end{array}$ & $\begin{array}{l}\mathrm{OM} \\
\mathrm{g} \mathrm{kg}^{-1}\end{array}$ & $\mathrm{Ca}^{2+}$ & $\mathrm{Mg}^{2+}$ & $\mathrm{K}^{+}$ & $\begin{array}{c}\mathrm{Al}^{3+} \\
\mathrm{cmol} \mathrm{d}\end{array}$ & $\mathrm{H}+\mathrm{Al}$ & SB & $\mathrm{E}$ & $\begin{array}{l}\mathrm{V} \\
\%\end{array}$ & Zn & $\begin{array}{l}\mathrm{Fe} \\
-\mathrm{mg}\end{array}$ & 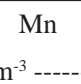 & $\mathrm{Cu}$ \\
\hline Substrate & 5.7 & 15.51 & 9.70 & 0.60 & 0.30 & 0.40 & 0.10 & 1.86 & 1.30 & 3.16 & 41.14 & 2.19 & 34.70 & 19.72 & 0.63 \\
\hline
\end{tabular}

SB: Sum of Bases; E: Cation Exchange Capacity (CEC); V: Base Saturação; OM: Organic Matter. 
The experimental design was of plots subdivided in time and arranged in a completely randomised design, with four replications of 10 plants per plot. The two treatments used in the plots were represented by the addition or not of nutrient solution; in the subplots, the treatments were represented by 10 evaluation periods ( 0 , $45,90,135,180,225,270,315,360,405$ and 450 days after transplanting).
Quantitative factors relating to height and diameter were statistically analysed using regression with the aid of the Sisvar software, with four replications of 10 plants per plot. The plants were kept in a nursery under $50 \%$ shading, and irrigated twice weekly with $50 \mathrm{~mL}$ of the nutrient solution (Table 2) by an automatic irrigation system, as proposed by Souza et al. (2017).

Table 2 - Composition of the nutrient solution used for the production of seedlings of the Brazil nut (Bertholletia excelsa)

\begin{tabular}{|c|c|c|c|c|c|c|c|c|c|c|c|}
\hline Composition & $\mathrm{N}-\mathrm{NO}_{3}-$ & $\mathrm{N}-\mathrm{NH}_{4}+$ & $\mathrm{P}$ & K & $\mathrm{Ca}$ & $\mathrm{Mg}$ & S & $\mathrm{Fe}$ & EC & [Ions] & Ionic strength \\
\hline & \multicolumn{8}{|c|}{$\mathrm{mg} \mathrm{L}^{-1}$} & Ds $\mathrm{m}^{-1}$ & & mmol L-1 \\
\hline Nutrient Solution & 174.0 & 24.0 & 39.0 & 183.0 & 142.0 & 38.0 & 52.0 & 32.0 & 1.74 & 26.92 & 21.94 \\
\hline
\end{tabular}

Every 45 days, the Bertholletia excelsa seedlings were evaluated for height (using a millimetre rule) and stem diameter (5 $\mathrm{cm}$ above the substrate, with the aid of a digital calliper).

Other variables under evaluation were the root and shoot dry weight. The roots were washed in running water to remove the substrate. The shoots and roots were then separately stored in paper bags and kept in a drying oven at $70^{\circ} \mathrm{C}$ for 72 hours. Once dry, the samples were weighed on a $0.01 \mathrm{~g}$ precision balance to determine the shoot dry weight (SDW, g plant ${ }^{-1}$ ) and root-system dry weight (RDW, g plant $\left.^{-1}\right)$; from the sum of these two values, the total dry weight of the plant (TDW) was calculated.

To measure seedling quality, the Dickson quality index (DQI) was used as a reference, using the formula proposed by Dickson et al. (1960).

The mean values of the variables were submitted to statistical analysis using the Sisvar software (Ferreira, 2011), employing analysis of variance and regression for the time factor (days), and Tukey's test at $5 \%$ probability for comparing the mean values of the remaining variables.

\section{RESULTS AND DISCUSSION}

The greatest mean values for height and stem diameter used in the production of seedlings of the Brazil nut (Bertholletia excelsa) were obtained by means of nutrient application (Figures 1A and B), meeting the standards recommended and regulated by decree no 37 , annex 4 , in which the seedlings should have a diameter of $10 \mathrm{~mm} 2 \mathrm{~cm}$ above the root collar; a height of $50 \mathrm{~cm}$ measured from the root collar; and be between 4 to 7 months of age, counted from planting. The Brazil nut (Bertholletia excelsa) seedlings that received the addition of nutrient solution, therefore met the established standards (Figure 1A).

According to Alves et al. (2016), shoot length, together with stem diameter, is one of the most important morphological characteristics for estimating seedling growth after final planting in the field. In the treatment where the plants received nutrient solution, the height and diameter of the stem were twice as large as the seedlings that received no nutrient solution.

These results showed that the sand + soil substrate $(3: 1 \mathrm{v} / \mathrm{v})$ irrigated with water only, did not provide enough nutrients to meet the requirements of the Bertholletia excelsa seedlings, and resemble results obtained by Smiderle et al. (2017a), who evaluated 'sweet cedar' (Pochota fendleri) for the application of nutrient solution.

A positive effect of nutrient solution on biomass production in seedlings of Cinnamon (Cinnamomum zeylanicum), 'Pau-rainha' (Centrolobium paraense), and African mahogany (Khaya ivorensis and Khaya senegalensis) are reported by Smiderle \& Souza (2016), Smiderle et al. (2016), Smiderle et al. (2017b) and Alves et al. (2016).

Analysing shoot dry weight (SDW) in seedlings of Bertholletia excelsa, an increase of $85 \%$ can be seen for the presence of nutrient solution when compared to the absence of nutrient solution (Table 3). On the other hand, for rootsystem dry weight (RDW), this increase was 43\%. As seen for most variables, there was also a gain of $62 \%$ in total dry weight (TDW) with the addition of nutrient solution (Table 3). This highlights the low potential of the substrate composed of sand + soil $(3: 1 \mathrm{v} / \mathrm{v})$ as an alternative in the 
production of Brazil-nut (Bertholletia excelsa) seedlings, since the established minimum measurements were not achieved even after 450 days.
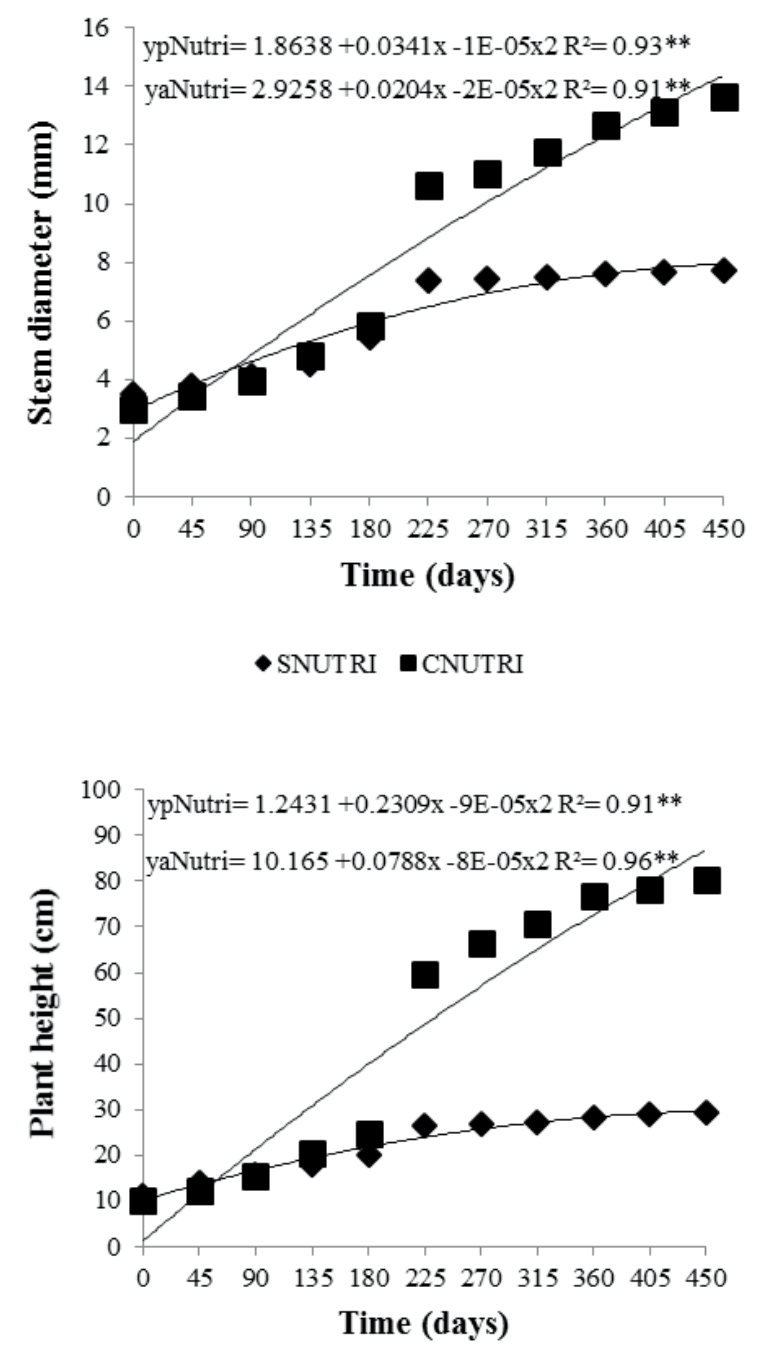

- SNUTRI aCNUTRI

Figure 1 - Seedling height (A) and stem diameter (B) in seedlings of Bertholletia excelsa with and without nutrient solution, grown for 450 DAT in a nursery under sombrite at 50\% luminosity.

According to Pimentel-Gomes \& Garcia (2002), the variability of an attribute can be classified according to the magnitude of its coefficient of variation, which can be:
Table 3 - Mean values for shoot dry weight (SDW, g), rootsystem dry weight (RDW, g), total dry weight (TDW, g) and Dickson quality index (DQI) in seedlings of Bertholletia excelsa with and without nutrient solution, grown for 450 DAT in a nursery under sombrite at 50\% luminosity

\begin{tabular}{ccccc}
\hline Nutrient Solution & SDW & RDW & TDW & DQI \\
\hline Without NS & $11.58 \mathrm{~b}$ & $41.03 \mathrm{~b}$ & $52.61 \mathrm{~b}$ & $12.95 \mathrm{~b}$ \\
With NS & $73.08 \mathrm{a}$ & $71.47 \mathrm{a}$ & $144.55 \mathrm{a}$ & $20.98 \mathrm{a}$ \\
\hline CV\% & 13.92 & 12.03 & 12.37 & 9.92 \\
\hline
\end{tabular}

*Mean values followed by the same letter in a column do not differ by Tukey's test $(p>5 \%)$.

(a) low, when less than 10\%; (b) average, when between 10 and 20\%; (c) high, when between 20 and 30\%; and (d) very high, if greater than $30 \%$. Thus, it can be seen that for the present study, the causes of variation are in the low and middle variation classes. Similar coefficients of variation to those of the present study were also found by Prado et al. (2008) and Chagas et al. (2013).

With regard to this work, the procedure employed for the use of substrates formulated with different mixtures of materials, such as sand and soil with nutrient solution, is a sustainable alternative aiming to reduce the costs and time of producing Brazil-nut seedlings of high morphological quality.

It can therefore be seen that the results found in the present study agree with those of Smiderle et al. (2017b), since the treatment which included the application of nutrient solution had the highest DQI and also gave results similar to those cited by the authors. Furthermore, according to the authors, the morphological parameters and the relationships used to evaluate the quality of the seedling should not be used on their own for classifying standard seedling quality, to avoid the risk of selecting taller but weaker seedlings, and discarding seedlings that are smaller but of greater vigour.

For that reason, the DQI is a good indicator of seedling quality, as several important parameters used to evaluate quality are considered in its calculation. In general, it can be seen that the addition of nutrient solution to the substrate, besides guaranteeing good seedling growth and quality, is the principal way the nurseryman has of "holding back" or "advancing" seedling growth in the nursery. This gives greater flexibility for when to plant the seedlings in the field, with no significant loss of technical quality.

Finally, it was found that among the treatments under evaluation, the application of nutrient solution 
resulted in higher values for the biometric attributes of the seedlings and in better values for the indices expressing quality, guaranteeing greater vigour (Table 3).

From the results of the present study, it can be seen that the Brazil nut (Bertholletia excelsa) displays rapid initial growth, with great growth potential in the field, as highlighted by Scoles et al. (2011), who, analysing the growth and survival of the Brazil-nut (Bertholletia excelsa, Lecythidaceae) under different environmental conditions from experimental plantations in the region of the Trombetas river, found that Bertholletia excelsa stood out for growth.

Tonini et al. (2011) also saw the potential of this species, and in studies into the relationship between seed production in native Brazil-nut trees and the morphometric characteristics of the crown and competition indices in the State of Roraima, found that the most productive trees of Bertholletia excelsa have higher growth rates and narrower, sturdier (thinner) crowns.

\section{CONCLUSION}

The addition of nutrient solution is indicated for obtaining greater growth and development in Brazil nut seedlings (Bertholletia excelsa) of high morphological quality for commercial use.

\section{ACKNOWLEDGEMENTS}

The authors would like to thank the Conselho Nacional de Desenvolvimento Científico e Tecnológico (CNPq) and the Coordenação de Aperfeiçoamento de Pessoal de Nível Superior (CAPES) for the research productivity grants awarded to the second author.

\section{REFERENCES}

ALVES, M.S.; SMIDERLE, O.J.; SOUZA, A.G.; CHAGAS, E.A.; FAGUNDES P.R.O.; SOUZA O.M. Crescimento e marcha de absorção de nutrientes em mudas de Khaya ivorensis. Acta Iguazu, v.5, n.3, p. 95-110, 2016. http://e-revista.unioeste.br/index.php/actaiguazu/article/ view/16257/11020.

ARAÚJO, W.F.; ANDRADE JÚNIOR, A.S.; MEDEIROS, R.D.; SAMPAIO R.A. Precipitação pluviométrica provável em Boa Vista, Estado de Roraima, Brasil. Revista Brasileira de Engenharia Agrícola e Ambiental, v.5, n.3, p.563-567, 2001.
BORGES, J.D. Viveiros florestais: projeto, instalação, manejo e comercialização. Brasília: Rede de Sementes do Cerrado, 2001, 27 p.

CORCIOLI, G.; BORGES, J.D.; JESUS, R.P. Sintomas de deficiência nutricional de macronutrientes em mudas de Khaya ivorensis cultivadas em solução nutritiva. Pesquisa Florestal Brasileira, v.34, n.78, p.159-164. 2014. https://pfb. cnpf.embrapa.br/pfb/index.php/pfb/article/view/641

CHAGAS, E.A.; RIBEIRO, M.I.G.; SOUZA, O.M.; SANTOS, V.A.; LOZANO, R.M.B.; LIMA, C.G.B. Alternatives substrates for production of seedlings camucamu. Amazonian Journal of Agricultural and Environmental Sciences, v.56, n.3, p.6-12. 2013. periodicos.ufra.edu.br/ index.php/ajaes/article/view/1466

DICKSON, A.; LEAD, A.L.; OSMER, J.F. Quality appraisal of white spruce and white pine seedling stock in nurseries. Forestry chronicle, v.36, n.1, p.10-13, 1960.

FERREIRA, D.F. Sisvar: a computer statistical analysis system. Ciência e Agrotecnologia, v.35, n.6, p.10391042, 2011. www.scielo.br/scielo.php?script=sci_ arttext\&pid=S1413-70542011000600001

FREITAS, N.; PRADO, R.M.; ROZANE, D.E.; TORRES, M.H.; AROUCA, M.B. Marcha de absorção de nutrientes e crescimento de mudas de caramboleira enxertada com cultivar Nota-10. Semina, v.32, n.4, p.1231-1242, 2011. www.uel.br/ revistas/uel/index.php/semagrarias/article/.../8888

FURLANI, P.R.; SILVEIRA, L.C.P.; BOLONHEZI, D.; FAQUIN, V. Cultivo hidropônico de plantas. Campinas: Instituto Agronômico, 1999, 52p. (Boletim Técnico, 180)

GONÇALVES, J.F.C.; SILVA, C.E.M.; JUSTINO, G.C.; JUNIOR, A.R.N. Efeito do ambiente de luz no crescimento de plantas jovens de mogno (Swietenia macrophylla King). Scientia Forestalis, v.40, n.4, p.337-344, 2012. www.ipef.br/ publicacoes/scientia/nr95/cap04.pdf

LORENZI, H. Árvores brasileiras: manual de identificação e cultivo de plantas arbóreas nativas do Brasil. 5 ed. Nova Odessa: Ed. Plantarum Ltda. 2008, 384p.

MAUÉS, M.M.; KRUG C.; WADT, L.H.O.; DRUMOND, M.C.C.; SANTOS, A.C.S. A castanheira-do-brasil: avanços no conhecimento das práticas amigáveis à polinização. Rio de Janeiro: Funbio, 2015, 78 p.

MOURA, E.A.; CHAGAS, P.C.; MOURA, M.L.S.; SOUZA, O.M.; CHAGAS, E.A. Emergência e desenvolvimento inicial de plântulas de cupuaçu cultivadas sob diferentes substratos e condições de sombreamento. Revista Agro@, mbiente, v.9, n.4, p.405-413, 2015. https://revista.ufrr.br/ agroambiente/article/view/2597

OLIVEIRA, J.M.F.; SOUZA, A.G.; SMIDERLE, O.J.; SANTOS, J.L.; DALL'AGNESE, L. Seedling production 
Cattleya eldorado in substrates with nutritive solution under shading screens. Acta Iguazu, v.6, n.4, p.114-125, 2017. e-revista.unioeste.br/index.php/actaiguazu/article/ view/16549.

PIAS, O.H.C.; BERGHETTI, J.; SOMAVILLA, L.; CANTARELLI, E.B. Produção de mudas de cedro em função de tipos de recipiente e fontes de fertilizante. Pesquisa Florestal Brasileira, v.35, n.3, p.153-158, 2015. https://pfb. cnpf.embrapa.br/pfb/index.php/pfb/article/.../714/422

PIMENTEL-GOMES, F.; GARCIA, C.H. Estatística aplicada a experimentos agronômicos eflorestais: exposição com exemplos e orientações pra uso de aplicativos. Piracicaba: FEALQ. 2002. 309p.

PRADO, R.M.; ROZANE, D.E.; CAMAROTTI, G.S.; CORREIA, M.A.R.; NATALE, W.; BARBOSA, J.C.; BEUTLER, A.N. Nitrogênio, fósforo e potássio na nutrição e na produção de mudas de laranjeira valência, enxertada sobre citrumeleiro 'Swingle'. Revista Brasileira de Fruticultura, v.30, n.3, p.812-817, 2008. www.scielo.br/ scielo.php?script=sci_arttext\&pid=S0100.

ROZANE, D.E.; PRADO, R.M.; NATELE, W.; ROMUALDO, L.M.; SOUZA, H.A.; SILVA, S.H.M.G. Produção de mudas de caramboleiras B-10 e Golden Star: II - Marcha de absorção e acúmulo de nutrientes. Revista Brasileira de Fruticultura, v.33, n.4, p.1308-1321, 2011. www.scielo.br/scielo.php?pid=S0100...script=sci_abstract.

SCOLES, R.; GRIBELL, R.; KLEIN, G.N. Crescimento e sobrevivência de castanheira (Bertholletia excelsa Bonpl.) em diferentes condições ambientais na região do rio Trombetas, Oriximiná, Pará. Boletim do museu paraense Emílio Goeldi. Ciências Naturais, v.6, n.3, p.273293, 2011. http://scielo.iec.gov.br/scielo.php?script=sci_ arttext\&pid=S1981-81142011000300004

SMIDERLE, O.J.; SOUZA, A.G. Production and quality of Cinnamomum zeylanicum Blume seedlings cultivated in nutrient solution. Revista Brasileira de Ciências Agrárias, v.11, n.3, p.104-110, 2016. www.redalyc.org/articulo. oa?id=119046408007.

SMIDERLE, O.J.; SOUZA, A.G.; CHAGAS, E.A.; SOUZA, M.A.; FAGUNDES, P.R.O. Growth and nutritional status and quality of Khaya senegalensis seedlings. Revista Ciências Agrárias, v.59, n.2, p.47-53, 2016. https://periodicos.ufra. edu.br/index.php/ajaes/article/view/2160.

SMIDERLE, O.J.; SOUZA, A.G.; SCHWENGBER, L.A.; SCHWENGBER, D.R. Shading of seedlings of paurainha and the use of fertilized substrate. Revista Espacios, v.38, n.33, p.213-218, 2017a. https://www.researchgate. net/.../318745657_Shading_of_seedlings_

SMIDERLE, O.J.; SOUZA, A.G.; PEDROZO, C.A.; LIMA, C.G.B. Nutrient solution and substrates for 'cedro doce' (Pochota fendleri) seedling production. Revista Brasileira de Engenharia Agricola e Ambiental, v.21, n.4, p.227-231, 2017b. www.scielo.br/scielo.php?script=sci_ arttext\&pid=S1415.

SOUZA, A.G.; CHALFUN, N.N.J.; FAQUIN, V.; SOUZA, A.A.; NETO, A.L.S. Production of peach grafts under hydroponic conditions. Ciência e Agrotecnologia, n.2, v.35, p.322-326, 2011. www.scielo.br/scielo.php?script=sci_ arttext\&pid=S1413-7054201100020001

SOUZA, A.G.; FAQUIN, V.; CHALFUN, N.N.J.; SOUZA, A.A. Produção de mudas tangerineira 'Pokan" em sistema hidropônico. Revista Ciência Agronômica, v.44, n.4, p. 296-297, 2013. http://www.scielo.br/scielo.php?script=sci_ arttext\&pid=S1806-66902013000400029

SOUZA, A.G.; CHALFUN, N.N.J.; FAQUIN, V.; SOUZA, A.A.; NETO, A.L.S. Massa seca e acúmulo de nutrientes em mudas enxertadas de pereira em sistema hidropônico. Revista Brasileira de Fruticultura, v.37, n.1, p.240-246, 2015. _www. scielo.br/scielo.php?pid=S0100...script=sci_abstract.

SOUZA, A.G.; SMIDERLE, O.J.; SPINELLI, V.M.; SOUZA, R.O.; BIANCHI, V.B. Optimization of germination and initial quality of seedlings of Prunus persica tree rootstocks. Journal of Seed Science, v.39, n.4, p.166-173, 2017. www.scielo.br/scielo.php?script=sci_ arttext\&pid=S2317-15372017000200166

SOUZA, A.G.; RITTERBUSCH, C.W.; MENEGATTI, R.D.; SMIDERLE, O.J.; BIANCHI, V.B. Nutritional efficiency and morphophysiological aspects with growth in the 'Okinawa Roxo' peach rootstock. Journal of Agricultural Science, v.11, n.9, 2019. http://www.ccsenet.org/journal/ index.php/jas/issue/view/0/2116

TONINI, H. Fenologia da castanheira-do-brasil (Bertholletia excelsa Humb. \& Bonpl. Lecythidaceae) no sul do estado de Roraima. Cerne, v.17, n.1, p.123-131, 2011.

www.scielo.br/scielo.php?pid=S0104...script=sci_abstract. TONINI, H.; KAMINSKI, P.E.; COSTA, P. Relação da produção de sementes de castanha-do-brasil com características morfométricas da copa e índices de competição. Pesquisa Agropecuária Brasileira, v.43, n.11, p.1509-1516, 2008. www.scielo.br/scielo.php?script=sci_ arttext\&pid=S0100

Recebido para publicação em 10/01/2019 e aprovado em 12/09/2019. 